\title{
REFLECTIONS ON DIRECT AND INDIRECT STRATEGIES OF POLITENESS IN G. B. SHAW'S PYGMALION: A SATIRE ON CONVENTIONALITIES OF POLITENESS
}

\author{
Do Thu Huong*, Nguyen Viet Ky \\ VNU University of Languages and International Studies \\ Pham Van Dong, Cau Giay, Hanoi, Vietnam
}

Received 27 May 2019

Revised 18 July 2019; Accepted 26 July 2019

\begin{abstract}
This study aims at investigating male and female strategies of directness and indirectness manifest in the speech of the characters in the play Pygmalion by George Bernard Shaw. In the light of politeness theory by Brown and Levinson (1978), the realizations of direct and indirect strategies of politeness are associated with two types of strategies of face threatening acts (FTAs), namely bald-on-record and offrecord strategies. The off-record strategy, which is the main focus of the study, is examined in relation to various sub-strategies of indirectness which are described in terms of the Gricean conversational maxims (i.e. Quantity, Quality, Relevance and Manner). These sub-strategies include the use of metaphors, irony, rhetorical questions, understatements and overstatements. A statistical survey is conducted on the frequencies of two politeness indicators, namely the bald-on-record strategies and tentativeness devices employed by the characters from different social classes in the play. The methodology of qualitative analysis employed in this study is based on Brown \& Levinson's theoretical framework of politeness with the main focus on the two components of communication: gender and social classes. In the play, the gap between the high and low classes in the late $19^{\text {th }}$ century British society is manifest in such differences of language use as phonetics, lexis, grammar, and pragmatics.
\end{abstract}

Keywords: politeness, face threatening acts, direct and indirect strategies of politeness

\section{Introduction}

It is a matter of common knowledge that the phenomenon of politeness is of great importance in every society as it is generally seen as a measure of social order in human civilization. Due to its significance in human life, there have been various studies on politeness-related issues in sociolinguistics, pragmatics, applied linguistics, social psychology, conversation analysis and anthropology; these studies have contributed to the enrichment of modern linguistics, in general, and our understanding of politeness

* Corresponding author. Tel.: 84-0977881998

Email: huongdo72@yahoo.com phenomena, in particular. As politeness phenomena are reflected in language, especially in verbal communication, the study of politeness is, therefore, based on language use and social interaction. To be "basic to the production of social order, and a precondition of human cooperation", the importance of politeness is undeniable in establishing and maintaining social order as well as interpersonal relationships (Brown \& Levinson 1978: xiii).

Among various works on politeness strategies, the study by Brown and Levinson (1978) is still considered thoroughly analytical. Of their four super-strategies for performing face threatening acts (FTAs), 
i.e. positive politeness, negative politeness, bald-on-record and off-record, the last two can be seen as directness and indirectness strategies, which are commonly employed in everyday life verbal interactions for the sake of politeness.

Not only in real life verbal interactions are politeness-based directness and indirectness clearly reflected, they also find their expressions vividly presented in various literary genres, especially prose and drama. Generally seen as period-specific reflections of real life situations, literary works are, however, usually affected by personal idiosyncrasies of the writer. This is particularly true in the case of the play Pygmalion by the British writer George Bernard Shaw as its main male character Professor Higgins, with his straightforward language, projects the playwright's protest against the social segregation of $19^{\text {th }}$ century British society. In this play, the phenomena of directness and indirectness as politeness strategies are subtly dealt with on the basis of a transformation process of Eliza Doolittle, a low-class girl, into a disguised high-class member. The linguistic transformation of this female character and radical changes in her speech behaviour, as well as Mr. Higgins's violations of politeness norms have inspired the author to conduct the present study in the light of politeness theory by Brown and Levinson (1978). Gender-based differences in direct and indirect strategies of politeness in the play Pygmalion are, therefore, analysed in terms of the bald-on-record and off-record strategies proposed by Brown and Levinson in the hope of finding out to what extent the characters' strategies of politeness differ from social expectations of polite speech and behaviour. In this research, the following abbreviations are used:
S: the speaker
H: the hearer

DSA: direct speech act

IDSA: indirect speech act

FTA: face threatening act

RQ: rhetorical question

RP: received pronunciation

\section{Literature review}

\subsection{Language and gender}

Every society is made up of men and women living, working and socializing with each other under respective socio-economic conditions with their shared cultural values and social norms. However, the differences between the two sexes can be noticed in various social aspects such as educational opportunities, job allocation, and power distribution. One aspect where male and female differences are vividly reflected is that of language use.

The fact that men and women speak differently is partly due to biological differences in their speech organs. However, it is not the difference in voice quality (presumably a natural fact) that accounts for gender-based differences in speech. The gender-specific use of language is determined by the culture and society in which the language under question is embedded.

It is true that any language is rulegoverned in terms of phonology, lexicon, and grammar. The relation between language and gender, however, is not restricted to such linguistic components, but is affected by a number of social factors such as class, status, power, and distance. To put it another way, a language does not evolve by itself but is a product shaped by society. It is "by virtue of its members having desires and preferences that 
the speech community creates and perpetuates its language" (Coulmas 2005: 7). In this sense, the social and cultural construction of gender plays an important role in gender-bound differences in language. In an egalitarian society where the inferior status of women is still a marked phenomenon, differences can be found in the use of linguistic forms and patterns of speech behaviour typical of men and women. For instance, in a study of New Yorkers' speech, women were found to use fewer non-standard forms than men. This is probably due to "the role of women as principal caregivers in child-rearing, which makes them more status-conscious" (Coulmas, 2005: 38). This finding was made by Labov (1990) and confirmed by Gordon (1997) who attributed women's standard speech forms to "their desire to teach their children the standard variety in order to enhance their future chances of social advance" (cited by Gordon in Coulmas, 2005: 38). Men's speech, on the contrary, tends to be more careless and less standard. It is partly due to the factor that in a male-dominated world, the men run no risk of having their superior status challenged by the women, a weaker sex. They, therefore, find it unnecessary to accommodate their speech to the standard forms. And quite interestingly, this assumption seems to be attested by the general public's attitude to male behaviour in speech. In almost all societies, men's use of swear or vulgar language is not an uncommon practice whereas bad language uttered by a woman is likely to produce a great shock. It is not wrong to say that the female choice of a more standard language use is determined by social expectations of their inferior and subordinate role compared with a superior and dominant role played by men in society.

A number of attempts have been made to find out the answer to a seemingly simple question "Why do men and women talk differently?" (Coulmas, 2005: 38). Two approaches proposed by linguists and researchers, namely, the Dominance approach and the Difference approach, can partly explain this.

"The Dominance approach focuses on power and equality" (Coulmas 2005: 39) and accepts a view of women as an inferior, oppressed and marginalized group. This theory interprets gender differences in language as the reflection of men's domination and women's subordination, an attitude that is manifest in family and in society. For instance, in a western family, the wife is supposed to bear her husband's surname, and her children to carry the family name of their father. These naming conventions are interpreted by Gibbon not as a neutral practice, but as the manifestation of male dominance, which is no less vividly demonstrated outside the family (1999: 61). Take the workplace for example. It is often the men who are likely to be given more job opportunities, more chances of job advancement as well as more high-powered and responsible jobs compared with their female partners.

The Dominance theory is also applied to explain gender-based differences in language use. Researchers have found that women appear less confident and assertive than men in mixedsex conversations, and they tend to use more questions, especially tag questions and hedges to ease their subordination and facilitate the conversation presumably dominated by men (Yule, 2006: 224). The fact that women use less interruptions and seem to show agreement to create a friendly atmosphere and thus avoiding conflicts in their talks (especially with men) is believed to be another signal of their inferior status and submission to men.

The Difference approach, on the other hand, relies on the argument that boys and 
girls are brought up separately within their own subcultural groups, therefore, they develop differences in terms of behaviour, attitude, and speech. As Coulmas puts it "different socialization patterns cause boys to be concerned with status and self-assertion, while girls are more geared to involvement and understanding" (2005: 38). The resulting conversational styles have been described as competitive and cooperative, respectively (Eckert, 1989; Tannen, 1991). In a sense, this approach seems to deny the dominating role of men and the submissive role of women. However, the existence of a male-dominated world together with sexist attitude reflected in language contradicts this view. In order to have a more objective understanding of how men and women talk, let us explore the coming section.

\subsection{Conversation and interaction}

Human life is filled with a large number of daily social encounters. At the market place, at school, at work or in any institutional settings, interpersonal exchange of utterances is a common practice.

Among different speech events, conversation is the most prevalent form of discourse, accounting for more than 90 per cent of all spoken language (Cheng, 2003: 12), and it is considered to be "the quintessence of spoken discourse" (Svartvik, 1980: 170). Seen as a pre-eminent form of language, conversation is a pre-genre in the sense that all genres, both spoken and written, are derived from it. Similarly, Fillmore (1981) states that conversational language constitutes the benchmark against which other forms of language can be compared and contrasted and that "once the syntax, semantics, and pragmatics of these basic types of discourse have been mastered, other types of discourse can be usefully described in terms of their deviation from such a base" (Fillmore, 1981: 165).

Though the type of conversation may vary depending on criteria such as age, sex, status, and relationship(s) of participants, it is assumed in most conversational exchanges that participants are cooperating with each other. This conversational principle, which is also known as Gricean principle, can be stated as follows: "Make your conversational contribution such as is required, at the stage at which it occurs, by the accepted purpose or direction of the talk exchange in which you are engaged" (Grice 1975: 45). This principle is supported by four maxims, often called as the "Gricean maxims".

- The Quantity Maxim: Make your contribution as informative as is required, but not more, or less, than is required.

- The Quality Maxim: Do not say that which you believe to be false or for which you lack adequate evidence.

- The Relevance Maxim: Be relevant

- The Manner Maxim: Be clear, brief and orderly (Yule, 2006: 130).

In a real life conversation, however, it is not always necessary for participants to strictly follow these maxims. They can choose to flout them from time to time without any intention of opting out of the talk exchange. When this occurs, a conversational implicature is triggered, a feature commonly found in literary works. A way to look for implicatures in conversations is to examine rhetorical strategies such as metaphors, irony, rhetorical questions, understatements, and overstatements, which are interpreted as flouts of the Gricean Quality maxim, or jokes which flout the Manner maxim.

Though one's speech behaviour is supposed to be socially and culturally determined, the fact that men and women's 
conversational styles tend to differ seems to hold true with any speech community. The concept of conversational style is considered by Tannen (1981) both as a social and individual phenomenon. When speakers from similar speech communities share the means of verbal communication such as lexicon, grammar, phonetics as well as certain paralinguistic features like pitch, amplitude, intonation, rate of speech, conversational style is a social phenomenon. On the contrary, style as an individual phenomenon is realized when speakers use particular features (especially body language like nodding, smiling, frowning, gestures, and postures) in particular settings. These two styles contribute to identifying the speaker as a member of a certain speech community. Though conversational styles differ from one speaker to another, it is generally agreed that women do share common linguistic features in their talk, thus distinguishing their style from that of men.

Studies have shown that "women are far less domineering in conversation and tend to favour co-operative or supportive participation" (Wray \& Bloomer, 2006: 106). They tend to give more back channel support (Wareing, 2004: 88). Men, on the contrary, tend to ignore comments of the other speaker by offering no response or acknowledgement at all (Hirschman, 1973: 11), by giving a "delayed minimal response" (Zimmerman \& West, 1975: 118), or by responding unenthusiastically (Wray \& Bloomer, 2006: 106).

Moreover, tentativeness devices including hedges (how say, I think, I believe, I feel, I guess, I mean) and qualifiers (well, you know, sort of, like, kind of, perhaps, really, maybe) together with epistemic model forms (should, would, could, may and might) are also employed more frequently by women (Ivy \& Backlund, 2004: 185). These indirect linguistic features serve as indicators of uncertainty on the part of the user, thus helping "dilute" assertions so as to avoid explicit confrontation if disagreement occurs in the conversation (Wareing, 2004: 88). And these very features are also seen as strategies of politeness in conversation. Men, on the contrary, can be seen as more competitive as they show a greater tendency to interrupt their partners, especially female ones (Zimmerman \& West, 1975: 118), and challenge or dispute their partners' utterances (Hirschman, 1973: 11). In addition, men make more direct declarations of fact or opinion than women (Fishman, 1978: 402), including suggestions, opinions, and "statements of orientation" as described by Strodbeck and Mann (1956), or "statements of focus and directives" as viewed by Soskin and John (1963) (cited in Maltz \& Borker, 1987: 198).

In sum, men's competitive speech style to gain "status" in their "report talk" whereas women's cooperative tendency to forge "intimacy" and "connection" in their "rapport talk" (Cameron, 1977) are major differences manifest in male and female conversational styles. Factors that affect what is communicated and how it is interpreted in an interaction are discussed next.

\subsection{Interaction}

Interaction is generally understood as communication that involves the exchange of information as well as the expression of feelings and thoughts among people. Yule states that interaction may apply to a large number of social encounters and settings in which "interpersonal exchange of talk" takes place and in which pre-conversation factors are mainly external factors (age and power) that typically involve the status of the participants. On the other hand, internal factors, such as the amount of imposition or 
degree of friendliness, are often negotiated during an interaction. "Both types of factors, external and internal, have an influence not only on what we say, but also on how we are interpreted" (Yule, 1996: 60). In other words, there are many factors that determine what and how one can communicate successfully. It is also worth mentioning that the success of any verbal communication depends on the interactants' awareness of politeness principles which are socially and culturally determined.

\subsection{Politeness}

Politeness is a universal phenomenon that finds its expression both verbally and nonverbally. Due to its ubiquity in language use, politeness has become an interesting subject for various linguistic studies.

\section{- Politeness and face}

As politeness phenomena have become a study object of many researchers, a great number of politeness concepts have been introduced. Culturally, politeness is seen as a "socially adequate behaviour", and as "the practice of organizing linguistic action so that it is seen as inoffensive and conforming to current social expectations regarding the trouble-free management of communication" (Coulmas, 2005: 84). Linguistically, politeness is defined as "the interactional balance achieved between two needs: the need for pragmatic clarity and the need to avoid coerciveness" (Blum-Kulka, 1987: 131). As viewed by France "politeness means learning to accommodate to others within a given social group", and when interpreted in a more negative way "politeness could be seen as an oppressive force, taming the individual, imposing conformity and deference" (1992: 4-5). It is generally agreed that the principles and specific norms of politeness are determined by social and cultural values known to the interactants, who are expected to take "face" into consideration in their polite behaviour in language use.

Brown and Levinson define face as "the public self-image that every member wants to claim for himself", and that "face is something that is emotionally invested, and that can be lost, maintained, or enhanced, and must be constantly attended to in interaction" (1978: 61). Face, as claimed by these two linguists, consists of negative face - "the need to be independent, to have freedom of action, and not to be imposed by others", and positive face - "the need to be accepted, even liked, by others, to be treated as a member of the same group, and to know that his or her wants are shared by others" (Yule 1996: 61-2). As speech acts often tend to impose on the hearer $(\mathrm{H})$ 's sense of face, politeness may be recognized as a means for the speaker (S) to show his/ her awareness of H's public self-image. In communication, people may give a threat to another individual's self-image or face want, thus leading to a face threatening act (FTA). Alternatively, people may choose to act in a way that lessens a possible threat to another's face, and this is termed a face saving act (FSA). Assuming these face-related notions to be acknowledged by interactants, Brown and Levinson (1978) proposed various politeness strategies categorized into four main types, namely Positive politeness, Negative politeness, Bald-on-record, and Off-record, which are dealt with in the next section.

\section{- Politeness strategies}

Grundy sees politeness strategies as "a way of encoding distance between speakers and their addresses" (2000: 145). In this sense, the more distant the interactants are to each other, the higher degree of politeness should be realized. Thus, positive politeness is defined by Yule as a FSA that tends to show solidarity and 
common goals of the speakers (1996: 62). As this strategy is likely to be used by members within a close-knit group, or by those who want to claim some common ground as a result of their cooperation in conversation, a choice of an informal style is preferred. Linguistically, the use of "nicknames, sometimes even abusive terms (particularly among males), and shared dialect or slang expressions" is common in the strategies of positive politeness (Yule, 1996: 65). Brown and Levinson (1978) in their comprehensive study on politeness suggested a list of sub-positive politeness strategies grouped under three main types, i.e. claim common ground, convey that the speaker and the hearer are cooperators, fulfil the hearer's want for something. This classification served as a starting point for further research on politeness.

Contrary to positive politeness, negative politeness is claimed by Yule to be a FSA oriented to the person's negative face with the aim to show deference as regards to the other's time or concerns, and "even includes an apology for the imposition and interruption" (1996: 62). Like positive politeness, negative politeness also comprises various strategies which are classified by Brown and Levinson (1978). Thus, they distinguish negative politeness strategies, which imply distance, deference, and the freedom of choice for the hearer, as more polite than positive ones.

Of the last two types of politeness strategies, bald-on-record and off-record, the former is often associated with directness while the latter with indirectness. The baldon-record strategy can be realized when direct address forms are applied by the speaker as means of expressing his/her needs, especially via the use of imperative forms (Yule, 1996: 63). Bald-on-record is particularly important in cases of great urgency and desperation, and it is seen by Brown and Levinson as the strategy that conforms with Grice's maxims (see section 2.2 for detail) in order to communicate most efficiently.

The off-record strategy (often referred to as hints), on the other hand, is employed by $\mathrm{S}$ when $\mathrm{s} /$ he uses indirect statements to realize his/her goal(s). Such rhetorical strategies as metaphors, irony, rhetorical questions, understatements, overstatements can function as the indicators of indirectness strategies. One disadvantage of the off-record strategy is that $\mathrm{S}$ does not always get what $\mathrm{s} / \mathrm{he}$ wants using indirect statement(s), and if his/her goal is met, it is only because more is communicated than is said. The distinction between direct and indirect speech acts is outlined in the next section.

\subsection{Directness vs. indirectness and their reaction to politeness}

Yule (1996: 54) distinguishes a direct speech act (DSA) from an indirect speech act (IDSA) on the structural basis of three distinctive sentence types, namely declarative, interrogative, and imperative. As each of these types is presumably attached to a certain function, i.e. statement, question, command/ request respectively, whenever there is a direct relationship between a structure and a function, a DSA is performed. On the contrary, an IDSA is realized when the sentence type contradicts its assumed function. Consider the following examples:
(a) It's stuffy in here.
(b) Could you pass the salt?
(c) Have a good journey!

The declarative sentence in (a) is used by S not just to describe a fact (a stuffy room), but to make a request to $\mathrm{H}$ to open the window or to turn on the fan/air-conditioner. As the sentence type does not fit its function, an IDSA is performed. Similarly, the interrogative form 
in (b) and the imperative pattern in (c) serve the functions of a request and a wish respectively instead of a question and a command/request as they are supposed to. They (b and c), therefore, provide other examples of IDSAs. Though people from different cultures hold different views on the use of DSAs and IDSAs with respect to politeness theory, it is generally acknowledged that IDSAs are associated with greater politeness than DSAs, an idea which is shared by Yule (1996) as far as the English language is concerned. The use of directnessindirectness in any verbal interaction is seen by Quang (1998) as being affected by various socio-cultural factors including age, sex, residence, mood, occupation, personality, topic, place, communicative environment/ setting, social distance, time pressure and position.

\section{Research methodology}

The data of the study is provided by utterances made by the male and female characters of the play Pygmalion by George Bernard Shaw published in 2008. As the work analyzes the speech of fictional characters which differs from utterances in real life situations, an interdisciplinary approach is employed. This approach comprises three methods. First, the linguistic-pragmatic analysis is used to describe gender-based differences in directness and indirectness strategies in the light of Brown and Levinson's politeness theory. These strategies include the bald-on-record and the off-record strategies, with the focus on the use of rhetorical questions, metaphors, irony, overstatements and understatements. Second, a literary analysis of the play Pygmalion as a social satire is integrated in the study. Finally, the quantitative analysis which is based on the statistical data on two politeness markers, namely the bald-on-record strategies and tentativeness devices is performed. This analysis assesses proportions between the number of words which each character employs for the two types of politeness strategies and the total number of words s/he uses throughout the play, thus distinguishing the characters' use of politeness strategies in statistical terms.

This social play is remarkably noted for its satirical representation of the British highclass society. Professor Higgins, the main character, is an expert in phonetics. This man is portrayed as an antipode to the stereotype of high-class men in the $19^{\text {th }}$ British society, as his behaviour and language are often in conflict with the politeness norms set by this class. In Pygmalion, instances of a straightforward and impolite language abound in Mr. Higgins' utterances. Professor Higgins's extravagant verbal interactions with other characters in the play seem to mock at the norms of the British polite society at that time. Similarly, the vivid presentation of the non-standard language used by the main female character, Eliza Doolittle (Liza), a low-class girl, as well as her linguistic progress after a six-month transformation into a "duchess", provide interesting data for a study of politeness strategies. Besides, the language usage of Mrs. Pearce, Mr. Higgins' housekeeper, and of Mr. Doolittle, a low-class man, provides differences in direct and indirect strategies of politeness employed by the characters from different social classes.

\section{Findings and discussion}

\subsection{Directness and indirectness strategies in the speech of female characters}

Theories of politeness tend to focus more on polite behaviour than on impolite behavior. 
However, it is an impolite, rude, discourteous type of behaviour that is most often noticed by commentators and participants. This means that a person's polite behaviour can be judged by investigating either his/her positive or negative ends of the politeness scale. This tendency seems appropriate for a study that is analyzing the behaviour of lowclass people as their use of a non-standard language may be interpreted as a challenge to politeness theories. In Pygmalion, Liza uses strategies of directness and indirectness in a way that does not conform to the norms of politeness strategies as described by Brown and Levinson's theory.

4.1.1. Directness and indirectness in Liza's speech: politeness strategies of a lowclass girl

\section{- Directness strategies}

Language is said to display its speaker's identity, and in the case of Eliza Doolittle, her language gives her away (Coulmas, 2005: 171). The lack of a proper education is a disadvantage to Liza in her talks with people from a higher class, and it may result in a communication breakdown. A number of DSAs are employed in Liza's speech.

(1) [....] buy a flower off a poor girl.

(2) Take this for tuppence.

(3) Oh, sir, don't let him lay a charge agen me for a word like that.

(4) Let him say what he likes.

(5) Take the whole blooming basket for sixpence.

Except for (3), an appeal made by Liza to a gentleman who may save her from getting into trouble with a stranger, the four imperative sentences above share the same feature, as they are all cases of nonminimization of the face threat, which are common in situations associated with urgency or desperation faced by $\mathrm{S}$.
The utterances 1-5 are made in a chance encountered between Liza and the two highclass gentlemen, Mr. Higgins and his friend, Colonel Pickering. As there is a great social distance between the girl and the two men, a formal conversational style is expected from Liza. This particular speech event is free from urgency and desperation, as Liza is persuading Pickering to buy flowers. However, Liza's imperatives in (1) and (2) are part of the speech acts which display the lack of concern for others' face despite the fact that they may comply to Grice's Conversational Principles, i.e., the principle of clarity. Liza's imperative [....] buy a flower off a poor girl, which functions as an appeal to a high-class member who she sees as a potential customer, is awkward in terms of politeness no matter how clearly her purpose is stated. Liza should have employed a more polite form of expression to achieve her goal. Similarly, considering the imposition impinged on $\mathrm{H}$, it is often considered awkward for a flower girl to make bald commands to her customer as in (2) and (5), who is in many ways superior to her. These imperatives $(1,2,5)$ may be considered as Liza's violations of the politeness postulates mentioned earlier. In the "let" structure in (4), which aims at granting permission, it would be more natural if the utterance were made by someone of a more powerful status, not by a low-class flower girl to a high-class member. That's why, (4) may be regarded as improper in this setting.

During Liza's visit to Mr. Higgins when she comes to ask him to teach her how to talk like a lady, the following imperatives are made:

(6) Don't you be so saucy.

(7) Oh, don't be silly.

These two imperatives, addressed to her prospective teacher and his friend, sound shocking as these utterances are seen as 
impertinent requests made by Liza. Except for (3), which is the most polite form with the use of the deferential term "sir" and reasonable wording, the rest of the imperatives mentioned earlier go against the common-sense norms of politeness. To conclude, Liza's direct style in her communication with the two high-class men may be interpreted as provocative.

\section{- Indirectness strategies}

In Liza's verbal interactions, some offrecord politeness strategies are employed as well, but the most prevailing one is the use of rhetorical questions (RQs). Usually, RQs are made not for information but mainly for the assertion of an idea already introduced. It is notable that a number of Liza's RQs function as assertive sentences. The following utterances illustrate this.

(8) Who's trying to deceive you?

(9) Oh, what harm is there in my leaving Lisson Grove?

(10) Who'd marry me?

These RQs can be interpreted as I'm not deceiving you, There's no harm in my leaving Lisson Grove, and Nobody would marry me, respectively. RQs are also used by Liza to convey more subtle implicatures, as in (11) and (12).

(11) Did you tell him I come in a taxi?

(12) Don't I tell you I'm bringing you business?

The RQ in (11) triggers the implicature that Liza has money, and she has come not to cause trouble but to offer some business beneficial to Professor Higgins, thus (11) conveys her claim for respect. This idea is confirmed by (12) when she indirectly states to Mr. Higgins that she may offer him some kind of employment for which he will be paid. What is remarkable in (11) and (12) is that Liza seems to show her confidence in gaining the support of her addressee, as her bald questions prove. The money she brings with her, though very little, enables her to talk as an equal to Mr. Higgins.

Apart from the rhetorical questions, the use of metaphor (a transference of some quality from one object to another) and understatement (a statement of restrained meaning) are other features in Liza's indirectness strategies, even though they are not employed frequently. Examples of metaphor and understatement are:

(13) Gin was mother's milk to her.

(14) If a man has a bit of a conscience, it always takes him when he's sober; and then it

makes him low-spirited. A drop of booze just takes that off and makes him happy.

In (13), by associating gin with mother's milk in her talk about her aunt, Liza indirectly implies the drinking habit of the latter, thus flouting the Quality maxim. The understatement in A drop of booze in (14) also flouts the Quality maxim as such a tiny amount of alcohol cannot have such an effect on its drinker as claimed by Liza. Though these two indirectness strategies are supposed to show S's politeness to $\mathrm{H}$, the choice of Liza's highly colloquial language (e.g. booze, it always takes him and takes that off) and an unsafe topic (her private family affairs) seem inappropriate in a formal social setting among high-class strangers. Thus, even in the case of indirect strategies, her speech behaviour appears to be impolite. In addition to this, the habit of self-appraisal and otherabasement is manifest in her speech as the following examples illustrate:

(15) Ought to be ashamed of himself, unmanly coward!

(16) You ought to be stuffed with nails, you ought.

(17) Oh you are a brute. It's a lie: nobody ever saw the sign of liquor on me. 
The ellipsis of he before ought to in (15) violates the politeness strategy of Claiming common ground supposedly employed by ingroup members, as in this case there is a great social distance between Liza and her referent (Mr. Higgins), and the interlocutors are in no way in-group members. Liza's remark in (16) sounds as if she were addressing someone of the same or of a lower status; as the addresser is not a person of this status, (16) sounds rude. Also, her bald declarative in (17) sounds discourteous, especially, as it is addressed to the high class member.

In Liza's speech, another characteristic can be recognized, namely the repetition of subject-pronouns followed by the corresponding forms of either the verb to be or auxiliary verbs. The following utterances exemplify this.

(18) He's off his chump, he is.

(19) You're no gentleman, you're not, to talk of such things. I'm a good girl, I am; and I know what the like of you are, I do.

(20) You're a great bully, you are.

These repetitions he is in (18), you're not, I am and I do in (19), and you are in (20) have an emphatic effect. More specifically, Liza indirectly implies her disappointment with the man in (18) while in (19) she shows how much she is hurt by H's suggestion and implicitly expresses her objection to it. Moreover, her feeling of helplessness while talking with $\mathrm{H}$, who is superior to her in terms of power and background, is indicated in (20). With this assertive language use, Liza intentionally makes her utterances more face threatening.

Being a low-class unschooled girl, Liza uses various non-standard forms, such as the double negation in (21) and (22), past tense instead of past participle in (23), ain't in place of isn't in (24), am not in (25) and haven't in (26) in the utterances below.
(21) I don't want to have no truck with him.

(22)I didn't want no clothes.

(23) You just show me what you've wrote about me.

(24) That ain't proper writing.

(25) I ain't dirty: I washed my face and hands afore I come, I did.

(26) I ain't got no parents.

Thus, as a flower girl, Liza faces a lot of problems in her verbal interactions with the high-class members, and her limited knowledge of politeness principles makes her an awkward interactant. In contrast to Liza, Mrs. Pearce, Mr. Higgins's house-keeper, epitomizes a model of polite behaviour cultivated by the British high society of Shaw's times.

4.1.2. Directness and indirectness strategies in Mrs. Pearce's speech

\section{- Directness strategies}

Unlike Liza, Mrs. Pearce is well aware of the social status and power relations between her and her master, Mr. Higgins. Therefore, her highly conventional behaviour is manifest in politeness strategies which she employs in her communication with Mr. Higgins. Thus, Mrs. Pearce rarely uses a direct conversational style unless in extreme cases. Her use of direct strategies is often accompanied by politeness markers, such as qualifiers and deferential address forms in order to reduce the face threat of her directness. This can be seen in the following utterances:

(27) Stop, Mr. Higgins.

(28) You must be reasonable, Mr. Higgins: really you must.

(29) Well, sir, [...], I beg you not to let the girl hear you repeat it.

(30) Do be sensible, sir.

Among these utterances, only (27) takes the form of an order in the imperative mood while 
the rest declaratives. The use of qualifiers such as really in (28) and well in (29), of deferential address forms like sir in (29) and (30), and of titles plus family names, as Mr. Higgins in (28), help soften the face threatening acts made by Mrs. Pearce. Moreover, these direct utterances reveal their entreating nature, which is most noticeable in (29) by means of a highly polite form of expression I beg you not to let the girl hear you repeat it. As this expression is preceded by the hedge well and followed by the deferential form of address sir, it becomes a highly polite request. Since these utterances are all task-oriented, to use the terms of Brown and Levinson (1978: 97), and at the same time, showing Mrs. Pearce's concern for Mr. Higgins's interest, such baldon-record instances should be regarded as politeness strategies.

However, Mrs. Pearce's tone of directness changes remarkably when her addressee is a low-class flower girl, Liza. The following bald-on-record statements illustrate this.

(31) Sit down, girl. Do as you're told.

(32) Don't cry, you silly girl. Sit down.

(33) Come with me, Eliza.

(34) You mustn't speak to the gentleman like that.

It is observable that Mrs. Pearce's use of marked address terms such as girl in (31) and you silly girl in (32) shows her contempt for Liza's low social status. This superior attitude to the low-class girl is also reflected in the imperatives (31-33) which function as orders. In (34), the employment of the strong modal verb mustn 't and the deferential term gentleman seems to contrast Mrs. Pearce's attitude to the addressee, Liza, and the referent, her master. Also, Mrs. Pearce's subservient manner, so manifest in her address to Mr. Higgins earlier, gives way to a more dominating manner when she addresses Liza. This supports the claim that "speakers adjust their speech behaviour to a particular social circumstance" (Coulmas, 2005: 18).

As indirectness is often associated with a higher level of politeness than directness, it is natural that a servant's strategies of directness are outnumbered by indirectness strategies in communication with a master, and this is exactly the case with Mrs. Pearce's use of direct strategies of politeness.

\section{- Indirectness strategies}

In her talks with Mr. Higgins, Mrs. Pearce uses numerous indicators of tentativeness, namely qualifiers and hedges, some of which are presented in the following instances:

(35) Well, sir, she says you'll be glad to see her when you know what she's come about.

[...] I should have sent her away, only I thought perhaps you wanted her to talk into your machines. I hope I've not done wrong; but really you see such queer people sometimes-you'll excuse me, I'm sure, sir-

(36) I think you'd better let me speak to the girl properly in private.

(37) Then might I ask you not to come down to breakfast in your dressing-gown, or at any rate not to use it as a napkin to the extent you do, sir.

In the above utterances, a number of qualifiers such as well, perhaps and really in (35), at any rate in (36), together with the hedges such as only I thought, I hope, you'll excuse me, I'm sure in (35) and I think in (36) are used. These qualifiers help soften the assertions in Mrs. Pearce's speech which supports the observations described in Wareing (2004: 88). Elements of tentativeness are not only restricted to this conventional lexicon, but also take a more subtle form. This is made clear in the use of modal verb structure as in I should have sent her away 
in (35), which suggests Mrs. Pearce's sense of duty as a servant to meet Mr. Higgins's expectations. These tentative expressions help create a rapport in the mixed-sex conversation between Mrs. Pearce and her master.

Indirect framings are also a common feature in the speech of Mrs. Pearce. This is made clear in the following utterances:

(38) Will you please keep to the point, Mr. Higgins.

(39) I want to know on what terms the girl is to be here.

(40) I just wish to trouble you with a word, if I may, Mr. Higgins.

(41) [...] but there is a certain word I must ask you not to use. [...] It begins with the same letter as bath.

The question form in (38) functions as a request, the declaratives imply a question in (39) or requests in (40) and (41); all these are instances of indirectness strategies. Together with the indirect reported speech of Liza's statement she says you'll be glad to see her when you know what she's come about followed by the face redress plus a deferential term in you'll excuse me, I'm sure, sir in (35), these indirect framings are used to minimize the face threat of the respective speech acts. The explicit politeness markers such as Will you please, if I may, Then might I ask you also contribute to the polite tone of expression employed by Mrs. Pearce to show her polite attitude to Professor Higgins.

This indirect style is typical of politeness common among high-class people, who tend to place more emphasis on courteous speech despite lengthy expressions required for this type of strategies. It is observable that this period-specific conversational style may be in conflict with the modern style of communication used by time-conscious interactants, who value the "What" more than the "How" of the information conveyed.

\subsubsection{Directness and indirectness} strategies in Liza's speech: a transformed high-class girl's politeness

Attracted by the prospects of a better life, Eliza determines to break away from her low class by opting for a new linguistic identity which may make her acceptable to the people from high society. From a deliciously low, horribly dirty flower girl, she becomes an elegantly disguised duchess after her six-month intensive training period. This transformation is achieved in the process of cooperative work with Professor Higgins, the author of Higgins's Universal Alphabet, and Colonel Pickering, the author of the book on spoken Sanskrit. Not only has her pronunciation improved to meet the standards of her interlocutors, high society people, her speech behaviour has converged accordingly.

\section{- Directness strategies}

Unlike the low-class flower girl in her former times, totally ignorant about the norms of polite behaviour, Liza is now well aware of politeness norms expected from her new presumably high-class identity. Her observations of the polite speech and manners of Mr. Pickering and Mrs. Pearce, two models of politeness, helped her master the norms of polite language and manners to such an extent that she finds it hard to use her former language. Her new linguistic identity is attested by her new conversational style that brings her closer to high society, linguistically and emotionally. It is not surprising to find Liza's bald-on record strategies occurring in a considerably restricted number. The following direct utterances illustrate this change in Liza's conversational style.

(42) Stop, please.

(43) Take your slippers; and may you never have a day's luck with them!

(44) Buy them yourself.

(45) Don't sneer at me. 
(46) Don't you hit me.

Compared with Liza's former speech, there is a notable difference in the use of direct style. Except for (42), where the use of the politeness marker please turns the utterance into an entreaty instead of an order, strategies in (43) and (44) may be regarded as instances of the face threat non-minimization. Although (43) and (44) may be considered as the FTAs, since Liza is not expected to use such a bald language when addressing Professor Higgins, the fact that Liza is strongly provoked by Mr. Higgins's contemptuous attitude to her justifies this bald-on-record strategy. Therefore, (43) and (44) should not be regarded as impolite. The imperatives in (45) and (46) share the same feature, as they both function as warnings (instead of orders) against some unreasonable action and attitude of Mr. Higgins. These illustrations comply with Brown and Levinson's politeness theory. Liza's strategies of indirect politeness definitely prove her adaptation to the conversational style characteristic of high society.

\section{- Indirectness strategies}

There is a strong link between Liza's new linguistic identity and the enrichment of her linguistic repertoire. This is manifest in Liza's use of rhetorical questions, which is still a prevailing feature in her speech.

(47) What am I fit for? What have you left me fit for? Where am I to go? What am I to do? What's to become of me?

These rhetorical questions certainly require no response from Mr. Higgins, but aim at making a complaint about Liza's presumably hopeless current situation. The chain of RQs in (47) indirectly asserts the given information, and these RQs may be interpreted as I am fit for nothing, I cannot go anywhere, I cannot do anything, and
I will become no one, respectively. Liza seems to blame her teacher, Mr. Higgins, for her new linguistic identity, which deprives her of the normal life of a lowclass flower girl.

Another new feature in Liza's speech is her frequent employment of tag questions, as in the following examples:

(48) I've won your bet for you, haven't I?

(49)Quite chilly this morning, isn't it?

The tag questions that Lisa uses are indirect ways of either asserting the information in (48) or seeking H's agreement in (49), and they can be interpreted as $S$ has won a bet for $H$, and it is a really chilly morning, respectively. It is also notable in (49) that there is a change in the tone of Liza in her address to Colonel Pickering. The intimate conversational style created by the ellipsis of It is, supposedly present in a more formal tag question It is quite chilly this morning, isn't it? seems to reveal Liza's self-confidence, thus presenting her as an equal to Colonel Pickering.

Liza's use of metaphors and irony also contributes to her linguistic transformation. Consider the following utterances:

(50) Why didn't you leave me where you picked me out of-in the gutter?

(51) Oh, I'm only a squashed cabbage leaf.

(52) You see it was so very difficult for me with the example of Professor Higgins always before me.

The metaphor in (50) you picked me out of-in the gutter ironically creates the image of a waste-product deserving no better place than a gutter. This waste-product is nobody else but Liza herself, and the gutter refers to her low station in life, the bottom of society. Another metaphor occurs in (51) where Liza associates herself with a squashed cabbage leaf. The untruthfulness of the utterance 
triggers the implicature that Liza's low status makes her pitiful, valueless and even useless in the eyes of high society, thus flouting the Quality maxim.

The utterance in (51) also serves as irony as it is actually Liza's repetition of Mr. Higgins's former remark made out of his hostility to her. In (52), Liza's ironic attitude is reflected in her use of the expression the example with a negative connotation, which is followed by a title plus surname Professor Higgins. (52) implies bad examples given by her teacher, who is, at the same time, working hard to turn her into a polite person. Ironically, it is Liza, his low-class pupil, who learns politeness norms by managing to avoid copying her teacher's discourteous manners and impolite language.

In addition to these strategies, instances of overstatements are noticed in Liza's speech.

(53) And there were a hundred little things you never noticed, because they came naturally to you.

(54) Oh, when I think of myself crawling under your feet and being trampled on and called names, when all the time I had only to lift up my finger to be as good as you, I could just kick myself.

The overstatements a hundred little things in (53), crawling under your feet, being trampled on and to lift up my finger to be as good as you in (54) are intentionally exaggerated, thus challenging the genuineness of these expressions. They flout the Quality maxim. Interestingly, the use of the passive voice (being trampled on) in these indirect expressions saves Liza from her direct criticism of Mr. Higgins's unfair treatment, which complies with the norms of politeness.
4.2. Directness and indirectness strategies in the speech of male characters

4.2.1. Directness and indirectness strategies in Professor Higgins's speech

Professor Higgins is seen throughout the play as a static character. Created by Bernard Shaw as a sarcastic member of high society, Mr. Higgins's view on politeness can be perceived as a deviation from the politeness norms set by his class. According to this character, the great secret is not having bad manners or good manners or any other particular sort of manners, but having the same manner for all human souls: in short, behaving as if you were in Heaven, where there are no third-class carriages, [...]. This extravagant and, at the same time, humanistic mode of thinking seems to govern his speech behaviour and manners, as he states to Liza in his burst of anger the question is not whether I treat you rudely, but whether you ever heard me treat anyone else better. This same-attitude treatment of everyone is best reflected in his language use, which is manifest in his direct and indirect strategies of politeness.

\section{- Directness strategies}

Mr. Higgins produces a great number of bald-on-record statements in his verbal interactions with other characters, especially with Liza. As mentioned earlier, Mr. Higgins admits his allegedly rude treatment of anyone and his impoliteness may be viewed as a typical feature of his speech. Consider the following utterances:

(55) Woman: cease this detestable boohooing instantly [...].

(56) Be off with you: I don't want you.

(57) Hold your tongue.

All these bald-on-record statements function as orders, and they are addressed to Liza. These non-minimizing FTAs sound 
highly impolite, and they are justified as Liza is a low-class flower girl, who is inferior to the addresser in her social status and power. In (55), the address form woman referring to a young girl in her twenties shows Mr. Higgins's sarcastic attitude to Liza. This imperative becomes even more face threatening with the ironic use of the expression detestable boohooing, which describes Liza's nonsensical verbal interaction. The adverb instantly employed in (55) seems to give more force to this speech act as it demands immediate obedience. In other words, (55) may be recognized as an order made by a highclass bully to his low-class female inferior.

This superior attitude is also felt in the next two bald-on-record statements (5657). These bald-on-record imperatives are pronounced when Mr. Higgins feels annoyed to see Liza, who can hardly explain the reason of her unexpected visit. As Professor Higgins is expecting someone who is really useful for his phonetic experiments, the unexpected appearance of the girl disappoints and irritates him, which accounts for his offensive order in (56). In (57), Mr. Higgins's discourteous manner becomes even more manifest as the utterance accompanies Mr. Higgins's repeated denial of response to Liza's questions.

Mr. Higgins's impoliteness is also notable in his requests to Mrs. Pearce, his servant, and Mr. Doolittle, Liza's father.

(58) Take all her clothes off and burn them.

\section{(59) Take your daughter.}

Though Mr. Higgins's order to his servant in (58) may be seen as task-oriented, to use the terms of Brown and Levinson's politeness theory, the message of this command is shocking to all those who hear it. As a high-class character, Mr. Higgins is not expected to talk and act as a ruffian, who would not care about consequences of his reckless command. The wording of $\mathrm{Mr}$. Higgins's imperatives violates the norms of politeness set by his own class.

Similarly, the abrupt request in $\mathrm{Mr}$. Higgins's address to Mr. Doolittle in (59) seriously threatens H's face. In this imperative, the referent is treated more like an inanimate object than a human being. Mr. Higgins's lack of concern for his interlocutor clearly shows his impoliteness.

To conclude, the above examples (only few among other direct utterances) are evidence of Mr. Higgins's intentionally impolite speech behaviour to his interlocutors, especially to the females. This can be arguably attributed to his odd bachelor's prejudice against women, who, in his opinion, are jealous, exacting, suspicious, and a damned nuisance. Mr. Higgins is portrayed as a confirmed bachelor, and his attitude to women is highly biased.

\section{- Indirectness strategies}

Mr. Higgins employs a variety of indirectness strategies, however in his own sarcastic way. Among these strategies, rhetorical questions, tag questions, and metaphors are most notable.

(60) Who's hurting you, you silly girl? What do you take me for?

(61) Pickering: shall we ask this baggage to sit down or shall we throw her out of the window?

In his first encounter with Liza in the beginning of the play, Mr. Higgins does not hesitate to show his utter contempt for her low status by means of rhetorical questions in (60). Being interpreted as Nobody is hurting you and I am a decent man, not a busybody as you may think, these two RQs show Mr. Higgins's antipathy to Liza who, in Mr. Higgins's mind, is incapable to judge about people. Moreover, the abrupt use of the address form you silly girl 
in (60) signals Mr. Higgins's lack of courtesy to a socially underprivileged member.

Furthermore, the alternative question in (61) includes rather sarcastic metaphors: this baggage in reference to the girl (a highly nonconventional metaphor) and throw her out of the window (an extended trite metaphor) actually imply ask her to leave. What is tricky in (61) is that the addressee, Pickering, is expected to choose one of these equally brutal options suggested in the utterance. The use of this baggage presupposes the baggage-like status of the referent, thus a hard choice for Mr. Pickering. Similarly, the metaphor throw her out of the window, which is interpreted as ask her to leave is hardly acceptable in this situation, as this utterance shows Mr. Higgins's discourteous behaviour, which is totally improper in this social setting.

Apart from these indirectness strategies, ironic expressions, overstatements, and understatements abound in Mr. Higgins's speech.

(62) She offers me two-fifths of her day's income for a lesson. Two-fifths of a millionaire's income for a day would be somewhere about 60 pounds. It's handsome. By George, it's enormous! It's the biggest offer I ever had.

(63) Somebody is going to touch you, with a broomstick, if you don't stop snivelling.

(64) By George, Eliza, the streets will be strewn with the bodies of men shooting themselves for your sake before I've done with you.

(65) It's almost irresistible. She's so deliciously low-so horribly dirty-

In (62), Mr. Higgins is ironic when he sarcastically remarks about the one-shilling fee which Liza offers to pay him for his phonetic lesson. To a celebrated professor of phonetics like Mr. Higgins, whose students are among commercial millionaires, Liza's offer is far too humble for his consideration.
A fee of one-shilling cannot be handsome or enormous, and it can never be the biggest offer Mr. Higgins has ever gained. Mr. Higgins is obviously flouting the Quality maxim here. By making fun of the trivial fee of one shilling by relating it to the fee of sixty pounds offered for one phonetic lesson by a millionaire learner, Mr. Higgins implicitly mocks at the job opportunity which Liza claims to be of mutual benefit for both of them.

The expression in (63) functions as an understatement as the phrase touch [...] with a broomstick is not meant literally but figuratively. Mr. Higgins's actual statement may be interpreted as You are going to be hit with a broomstick if you don't stop snivelling. In contrast to this utterance, (64) provides an example of ironic overstatement in which Mr. Higgins expands the possible result of his phonetic work on Liza. A wonderful transformation of this flower girl into an irresistible high-class lady whose claims result in streets strewn with the bodies of men shooting themselves for Liza's sake is a highly ironic hyperbole.

The richness of Mr. Higgins's language is also manifest in (65) where he wittily combines an overstatement and an understatement. Mr. Higgins's sophisticated play with language is reflected in the contrast of the understatement of deliciously low to the overstatement so horribly dirty. This phrase refers to Liza's low background and intellect, as well as her scruffy appearance, making any transformation work on her hardly possible within a six-month period. However, by contrasting It's almost irresistible and She's so deliciously low--so horribly dirty, Mr. Higgins shows his interest in training this girl phonetically so that her speech may meet the standards of cultivated language use. This decision seems to confirm his status of the greatest teacher alive, as 
remarked by Pickering, as far as phonetics is concerned.

Although Mr. Higgins's indirectness strategies are more elaborate and thus seemingly more polite than his directness strategies, his habitual use of swearing expressions such as devil, damn, damnably, what on earth is in conflict with his status as an educator and language expert.

To sum up, Mr. Higgins uses language in a way that is inappropriate for a person of his status as he violates the norms of politeness which he is expected to follow as a member of "polite society".

\subsubsection{Directness and indirectness strategies} in Mr. Doolittle's speech

\section{- Directness strategies}

Mr. Doolittle is an eccentric low-class man. Though poor, he does not mind his low status, as he baldly states that undeserving poverty is my line. He declares in his speech: I was happy. I was free. I touched pretty nigh everybody for money when I wanted it; his low position gives him happiness and freedom to lead his own life. Contrary to all expectations, in his talk to Mr. Higgins, Mr. Doolittle shows himself as a polite man, however, it is a different type of politeness. His inferior position compared to that of his interactant seems to account for this. The following baldon-record utterances addressed to Mr. Higgins illustrate this status-affected politeness.

(66) Don't take a man up like that, Governor.

(67) So help me, Governor, [...].

(68) No, Governor. Don't say that.

(69) Don't you give me none of your lip; and don 't let me hear you giving this gentleman any of it neither, or you'll hear from me about it.

It is notable that in (66-68) Mr. Doolittle intentionally uses the word Governor, a wrong choice of term, to address Professor Higgins.
This cunning low-class man is clever to employ this flattering term which shows his affected reverence mixed with intimidation, in the hope to manipulate $\mathrm{H}$ to his advantage. As to Mr. Doolittle's bald-on-record imperatives in the first three utterances (66-68), they function as entreaties; these imperatives are part of the politeness strategy characteristic of interactants of a lower social status.

In (69), the addressee is Liza, his daughter, and the imperative in (69) implies that, in Mr. Doolittle's opinion, Liza does not behave herself in the presence of Mr. Higgins and Colonel Pickering, high-class gentlemen. Thus, Mr. Doolittle uses this bald-on-record imperative as a warning for the sake of politeness.

Compared to Mr. Higgins' conversational style, Mr. Doolittle's style is affectedly polite, which may sound extravagant from a low-class man. However, after Mr. Doolittle has gained the status of a middle-class member thanks to an unexpected sum of three thousand pounds as an annual income from an American millionaire in return for Mr. Doolittle's lectures on moral reforms for the Wannafeller Moral Reform World League, there is a remarkable change in his conversational style. The once intimidated low-class Doolittle sounds more confident and assertive in his speech, which is observable in his utterances addressed to Mr. Higgins:

(70) See here! Do you see this? You done this.

(71) Look at it. Look at this hat. Look at this coat.

These face threatening acts convey his accusation of Mr. Higgins. According to Mr. Doolittle, Mr. Higgins is to blame for his new middle-class identity which deprives him of his former freedom and happiness. His former subservient attitude to Mr. Higgins is gone, and Mr. Doolittle talks as his equal or even as a person of superior rank. 
To conclude, Mr. Doolittle's direct strategies of politeness tend to change with the change of his social status from a lowclass man into a middle-class person. Mr. Doolittle's once affected politeness seems to be more straightforward now.

\section{- Indirectness strategies}

What is remarkable about Mr. Doolittle is that he, as Mr. Higgins puts it, has a certain natural gift of rhetoric; this gift displays itself in his utterances addressed to Professor Higgins, for example in (72).

(72) I'll tell you, Governor, if you only let me get a word in. I'm willing to tell you. I'm wanting to tell you. I'm waiting to tell you.

Here, parallel constructions contribute to Mr. Doolittle's rhetoric I'm willing to tell you. I'm wanting to tell you. I'm waiting to tell you, which is remarked as sentimental by Professor Higgins. Mr. Doolittle's natural gift of rhetoric is obvious in his indirectness strategies such as rhetorical questions, metaphors, irony, understatements, and overstatements. Thus, the utterances (73) and (74) are instances of rhetorical questions.

(73) Have I asked you for a brass farthing? I leave it to the gentleman here: have I said a word about money?

(74) Well, what would a man come for? Be human, governor.

In response to Mr. Higgins's accusation of a black-mail plot, Mr. Doolittle defends himself by the RQ in (73) which conveys his energetic protest: I have not asked you for any money and I have not said a word about money. In (74), another RQ, Mr. Doolittle does not explicitly state the reason for his coming, but the fact that he is poor and in need of money may be easily guessed. The RQ in (74) is followed by the appealing imperative
Be human, governor, which seems to confirm the purpose of his visit to Mr. Higgins, namely for money.

Mr. Doolittle's metaphoric and ironic expressions, as well as his understatements and overstatements are illustrated by the following utterances:

(75) I've heard all the preachers and all the prime ministers-for I'm a thinking man and game for politics or religion or social reform same as all the other amusements -

(76) The poor man's club, Governor: why shouldn't I?

(77) [...] I'll lecture them blue in the face, I will, and not turn a hair.

An overstatement is recognized in the utterance I've heard all the preachers and all the prime ministers in (75), which is a flout of the Quality maxim. As a low-class member, Mr. Doolittle tends to overstate in his speech, which is untypical of his class, thus making him a real eccentric. His bombastic language is also expressed in the extravagant statement in (75) for I'm a thinking man and game for politics or religion or social reform same as all the other amusements. The statement that politics, religion, and social reform are considered by this eccentric character as forms of entertainment sounds sarcastic. These rhetorical devices, namely overstatement and irony, help Mr. Doolittle avoid giving his frank opinion of preachers and prime ministers, whom he happened to hear. However, this opinion may be easily interpreted as derogatory.

In (76), an instance of understatement, also a witty metaphor, associates a pub with the poor man's club. As Mr. Doolittle's subtle use of this expression is likely to make him appear a pitiful poor man rather than a heavy drunkard, who he is, (76) flouts the Quality maxim. The metaphoric use of blue and not 
turn a hair in (77) makes this impulsive utterance said in response to Mr. Higgins's sarcastic remark about Mr. Doolittle's supposed status of the most original moralist an amusing example of rhetoric based on the contrast between the idioms of colloquial language and ironic overstatements and metaphors. The utterance in (77) may be interpreted as I'll lecture them straight to their face without any fear. This statement, together with those mentioned earlier, reveals Mr. Doolittle's boastful character.

At the same time, Mr. Doolittle's speech is full of non-standard forms such as the use of double negation in (78), the lack of verb concord in (79), the use of ain 't instead of aren't in (79), am not in (80), isn't in (81), haven't in (82), and -ed forms in place of irregular past participles in (83). These linguistic features occur in the following utterances:

(78) She said she didn't want no clothes.

(79) You and me is men of the world, ain't we?

(80) I ain't pretending to be deserving.

(81) She's a credit to me, ain't she?

(82) I take my Bible oath I ain't seen the girl these two months past.

(83) [...] she's growed big enough to be interesting $[\ldots]$.

Mr. Doolittle's use of tautology in form of tag question in (79), which flouts the Quantity maxim, is a lead-in, and prepares Professor Higgins for a serious talk. Other Quantityflouting statements in (78, 80 and 81) as well as the flouts of the Manner maxim in (82) and (83) characterize the indirect strategies of this character. Mr. Doolittle's witticisms and clever ways of flouting the maxims of various types portray him as a "great" but low-class "talker" owing to his non-standard English. As a result, his politeness strategies result in affectation.
To conclude, like Mr. Higgins, Mr. Doolittle is eccentric in his own way. Compared with Mr. Higgins's “impolite” conversational style, Mr. Doolittle's ostentatious speech seems to characterize him as a hypocrite in terms of verbal politeness. By contrast, Mr. Higgins, a sarcastic fictional character, seems to question the assumed politeness of the high society satirized by Bernard Shaw.

\subsection{A statistical survey of the bald-on-record strategies and tentativeness devices}

In Pygmalion, the characters from different social strata use strategies of directness (bald-on-record) and indirectness such as rhetorical questions, metaphors, irony, overstatements, understatements and tentativeness devices (off-record). However, the analysis of these strategies has shown that their use is not always in agreement with the postulates of the politeness theory suggested by Brown and Levinson, and these deviations specify individual strategies of politeness. Three objective factors that account for these deviations include class, status, and power. Of the four characters analyzed in section 4.1, only Mrs. Pearce, Mr. Higgins's house-keeper, strictly follows the norms of politeness due to her inferior status and power relation to Mr. Higgins. Her standard language and her stereotyped polite speech distinguish her from the other characters.

It may come as a surprise to the reader that Mr. Doolittle, a low-class man, ranks the second in terms of politeness. Despite the non-standard features of his language, common for a person of his social status and level of schooling, his speech is marked by the attempts to employ elaborate strategies of politeness. The awareness of his low status and a prospect for some money from his highclass interlocutor, Mr. Higgins, makes this 
man conform to politeness strategies which are uncommon in his social settings.

The other two characters, Mr. Higgins and Liza, are specific in terms of politeness strategies. In the case of Eliza Doolittle as a low-class flower girl, her non-standard language is not surprising, as it is the language commonly employed by her class. Due to the lack of access to proper education, Eliza is not acquainted with the norms of politeness in speech which distinguish high-class people, but she masters these norms after the transformation of her linguistic identity. As regards Mr. Higgins, he is expected to behave and talk in accordance with politeness norms set by high society, but he is a person who challenges the conventional nature of these norms, and his speech behaviour and manners are far from being polite, if judged in terms of conventional politeness.
In order to have an objective and statistically verified picture of politeness profiles, which characterize these four people, a survey is conducted with the focus on two indicators of politeness, namely the bald-on-record strategies and tentativeness devices. The data is provided by the characters' utterances and categorized into these two linguistic features. The number of words employed by each character in relation to each of these features is contrasted to the total number of words used by the respective character in the play, and percentages of this proportion are interpreted as markers of various degrees of politeness. The data on the use of the bald-on-record strategies and tentativeness devices is presented in Table 1.

Table 1. Occurrences of bald-on-record utterances and tentativeness devices

\begin{tabular}{|c|c|c|}
\hline Characters & Bald-on-record utterances & Tentativeness devices \\
\hline Eliza - a flower girl & $6.9 \%$ (124/1800 words) & $1.8 \%$ (34/1800 words) \\
\hline Eliza - a disguised high-class girl & $1.6 \%$ (36/2200 words) & $1.8 \%$ (41/2200 words) \\
\hline Mrs. Pearce & $15.7 \%$ (164/1042 words) & $5 \%$ (53/1042 words) \\
\hline Mr. Higgins & $5.2 \%$ (354/6870 words) & $1.4 \%$ (98/6870 words) \\
\hline Mr. Doolittle & $7.2 \%$ (195/2709 words) & $0.6 \%$ (16/2709 words) \\
\hline
\end{tabular}

Table 1 shows that the flower-girl Eliza uses 124 out of 1800 words, which is the total number of words spoken by her as a flower girl, to make bald-on-record statements, which ranks the third compared with the other three characters. However, a considerable change in Liza's use of bald-on-record strategy is observable when she gains a new linguistic identity after a six-month intensive training period. Not only is her new strategy characterized by a much lower frequency of bald-on-record utterances (1.6\% versus 6.9\%), but it has also undergone a considerable change in quality. Now her bald-on-record imperatives tend to conform to the norms of politeness. For example, in Liza's imperative Stop, please, which she addresses to $\mathrm{Mr}$. Higgins, the politeness marker please is used. Pragmatically, this politeness marker helps mitigate the face threat of the speech act and turns the bald-on-record statement into an entreaty.

In the case of Mrs. Pearce, whose use of the bald-on-record strategy is characterized by the highest proportion (15.7\%), this amount of imperatives does not identify her as an 
impolite person as her imperatives conform to politeness norms and show concern for the interests of others, as, for example, in the following instance.

(84) Don't answer back, girl. You don't understand the gentleman.

In (84), Mrs. Pearce advises Liza not to argue with Mr. Higgins, as the girl's poor communicative and argumentative skills may prevent her from a proper communication with her high-class interlocutor. This imperative is accompanied by the explication You don't understand the gentleman, thus making Mrs. Pearce's bald-on-record statement really sympathetic. According to Brown and Levinson, a sympathetic advice, as in the case of this example, may be regarded as a politeness strategy (see Appendix 2 for more examples).

Though Mr. Higgins's use of the baldon-record strategy only accounts for $5.2 \%$ of the whole amount of his words, he employs more bald-on-record words (358/6870 words) than the two female characters combined. A number of his direct imperatives may be interpreted as violations of politeness norms, for instance:

(85) Hold your tongue.

(86) Be off with you: I don't want you.

These instances of non-minimization of the FTAs (85-6) occur in Mr. Higgins's address to Liza before her transformation into an elegant high-class member (see Appendix 3 for more illustrations). His straightforward language sounds controversial for a member of "polite society". However, the fact that his interlocutors are females and inferior to him in status and power relations, Mrs. Pearce and Liza, may partly account for the FTAs of this confirmed high-class bachelor.

As regards Mr. Doolittle, his bald-onrecord strategy is characterized by the second highest proportion (7.2\%), which is $2 \%$ higher than Mr. Higgins's figure. Though bald-on-record utterances are often associated with a low level of politeness, most of $\mathrm{Mr}$. Doolittle's bald-on-record statements conform to politeness strategies, even though these strategies are inept in their choice of address terms.

(87) Don't say that, Governor. Don't look at it that way.

(88) Take my advice, Governor.

In (87) and (88), Mr. Doolittle's use of the deferential term Governor in his address to Mr. Higgins; even though it is an improper choice of the term, it softens the face threat of the imperatives and turns them into an appeal and advice, respectively. These types of politeness strategies are described by Brown and Levinson (see Appendix 4 for more examples).

Another indicator of politeness is related to the use of tentativeness devices such as hedges and qualifiers (see 2.2 for details). To judge from the data presented in Table 1, the speech of Mrs. Pearce has the highest percentage of these linguistic means (5\%); she epitomizes manners and speech behaviour of the so-called polite society. However, Mrs. Pearce may also overdo in her politeness since she is a house-keeper. This may explain the contrast between the percentages of the two women $5 \%$ vs. $1.8 \%$ since Liza has been taught to talk as a lady, not as a servant.

By contrast, Mr. Doolittle's employment of these devices, such as well, you know, you see, sort of, rates the lowest $(0.6 \%)$ among the four characters. This figure seems to contradict his ostentatious strategies of polite speech behaviour, but the fact that $\mathrm{Mr}$. Doolittle is an orator on moral reform may facilitate his speaking skills and helps him in his eccentrically polite communication 
with the upper-class characters. However, his rare use of tentativeness devices betrays the affected nature of politeness.

Mr. Higgins with the second lowest number of tentative words (98/6870 words) comes as no surprise to us. The percentages of $1.4 \%$ and $0.6 \%$ in Mr. Higgins's and Mr. Doolittle's use of these indirect features of politeness compared with the percentage of the female characters, $5 \%$ and $1.8 \%$, agree with the findings by Ivy and Backlund who maintain that men tend to use far less tentativeness devices than women (2004: 185). Some of the tentative words used by Mr. Higgins include hedges such as I think, I suppose, and qualifiers such as well, oh, you know. The low occurrences of this politeness indicator in the two male characters' speech also reveal a competitive nature commonly found in men in contrast to a cooperative tendency often seen in women (Cameron, 1977).

In the case of Liza's conversational styles, contrary to expectations, there is no change in her use of tentative expressions before and after her linguistic transformation. Compared with those employed by Mrs. Pearce (5\%), Liza's proportion is much smaller $(1.8 \%)$. Her straightforward nature (often noticed among low-class people) and her new linguistic identity as a high-class member, which is gained as a result of the cooperative work with Professor Higgins, may account for this.

To sum up, as reflections of real life people and situations, the characters in the play Pygmalion share gender-specific features described in previous studies of conversational styles, which facilitates judgments about their speech behaviour. However, as fictional characters, they also project their author's ideas about politeness, linguistic identity, and social conventions.

\section{Conclusion}

In his play Pygmalion, G. B. Shaw successfully portrays the fictional personas whose language provides interesting data for the analysis of politeness-based directness and indirectness strategies. In contrast to the two female characters, Mrs. Pearce and Eliza Doolittle as a flower girl, which may be regarded as truthful reflections of real life people of the high and low classes, Mr. Higgins and Mr. Doolittle stand out as exceptional representatives of the high class and low class people in the late $19^{\text {th }}$ British society. The image of a courteous British gentleman is challenged by the highly provocative speech behaviour of Mr. Higgins. This character intentionally violates the norms of politeness expected from a person of his class.

In the case of Mr. Doolittle, a low-class eccentric, his attempts to employ elaborate strategies of politeness are portrayed with humour. This ostentatious and cunning character is clever at using politeness strategies when he needs them to manipulate others for his personal gain.

It is also shown in the play that the gulf between the British high and low classes of Shaw's time is manifest in differences of language use, and these differences are phonetic, lexical, grammatical, and pragmatic. By giving Liza a new linguistic identity, Shaw seems to say to the world, especially the high society in Britain, that with the access to education, lowclass people have a chance to change their status and to climb up the social ladder to compete with high-class people. As regards Professor Higgins, it is no coincidence that he is portrayed as an expert in phonetics, thus making his amazing phonetic job on Liza a real social success since the Received Pronunciation accent which he taught Liza is a linguistic label of a high-class identity. However, it is ironical that this very character is by no means a model of politeness 
in his speech behaviour, as may be expected by his pupil, Liza.

As regards Eliza Doolittle, her acquisition of RP and grammar of Standard English is not enough to make her a polite person. It is reasonably remarked by Liza that the difference between a lady and a flower girl is not how she behaves, but how she is treated. It is not "the visible" but "the invisible" that counts in her transformation process from a low-class girl into a duchess, a masterpiece as claimed by Mr. Higgins. Toward the end of the play, the reader feels delighted to witness Liza's argumentative talk with her teacher, Mr. Higgins. It is her sensible and independent reasoning that makes Mr. Higgins, a person prejudiced against lowclass people, change his attitude to her and exclaim that Now you are a tower of strength: a consort battleship. Moreover, she is accepted by her arrogant teacher as an in-group member of his elite circle, which is manifest in his "paradoxical declaration" to her You and I and Pickering will be three old bachelors together instead of only two men and a silly girl.

To sum up, due to the complex relations between real life situations and those created by playwrights, fictional characters may deviate in their behaviour as they follow a scenario which conveys ideas of their author. Sometimes, these ideas may express protest against the superficial nature of conventional politenesss, which is the case with G. B. Shaw's play. Therefore, Pygmalion may be interpreted as a satire on conventional norms of politeness strategies analyzed by Brown and Levinson. It is strongly suggested that further studies of literary works in terms of directness and indirectness strategies should be carried out to describe the diversity of politeness strategies used by fictional characters.

\section{References}

Blum-Kulka, S. (1987). Indirectness and Politeness in Requests: Same or Difference? Journal of Pragmatics, Vol: 2, 131.

Brown, P. \& Levinson, S. C. (1978). Politeness: Some Universals in Language Usage. Cambridge: Cambridge University Press.

Cameron, D. (1977). Performing gender identity: Young men's talk and the construction of heterosexual masculinity. In A. Jaworski \& N. Coupland. eds. The Discourse Reader. London and New York: Routledge, 47-64

Cheng, W. (2003). Intercultural Conversation. Amsterdam/Philadelphia: John Benjamins Publishing Company.

Coulmas, F. (2005). Sociolinguistics. Cambridge: Cambridge University Press.

Eckert, P. (1989). The whole women: sex and gender differences in variation. Language Variation and Change, Vol: 1, 245-68.

Fillmore, C. J. (1981). Pragmatics and the description of discourse. In P. Cole. ed. Radical Pragmatics. Academic Press: New York. 143-166.

Fishman, P. M. (1978). Interaction: the work women do. Social Problems, Vol: 25, 397-406.

France, P. (1992). Politeness and Its Discontents: Problems in French Classical Culture. Cambridge: Cambridge University Press.

Gibbon, M. (1999). Feminist Perspectives on Language. London: Longman.

Gordon, E. (1997). Sex, speech and stereotypes: Why women's speech is closer to the standard. Language in Society, Vol: 26, 47-63.

Grice, P. (1975). Logic and Conversation. In P. Cole \& J. Morgan. eds. Syntax and Semantics 3. New York: Academic Press. 41-58.

Grundy, P. (2000). Doing Pragmatics. London: Arnold.

Hamilton, C. (1988). Using masculine generics. Sex Roles, Vol: 19, 785-799.

Hirschman, L. (1973). Female-male Differences in Conversational Interaction. Paper presented at Linguistics Society of America. San Diego. 11

Ivy, D. K. \& Backlund, P. (2004). Gender Speak. New York: Mc Graw Hill.

Labov, W. 1990. The intersection of sex and social class in the course of linguistic change. Language Variation and Change, Vol: 2, 205-54.

Maltz, D. N. \& Borker, R. A. (1987). A cultural approach to male-female miscommunication. In J. J. Gumperz. ed. Language and Social Identity. Cambridge: Cambridge University Press. 196-216. 
Quang, N. (1998). Vietnamese-American CrossCultural Differences in Extending and Encountering Compliments - as Seen from Communicative Activities. Unpublished Ph. D. Thesis. Vietnam National University. Vietnam.

Shaw, B. (1916). Pygmalion. Drama. 21 September 2008. $\quad<$ http://drama.eserver.org/plays/modern/ pygmalion/default.html >.

Strodbeck, F. L. \& Mann, R.D. (1956). Sex role differentiation in jury deliberations. Sociometry, Vol: 19, 3-11.

Svartvik, J. 1980. Well in conversation. In S. Greenbaum, G. Leech \& J. Svarvik. eds. Studies in English Linguistics. London: Longman,167-177.

Tannen, D. (1981). New York Jewish conversational style. International Journal of Sociology and Language, Vol: 30, 133-49.
Tannen, D. (1991). You Just Don't Understand: Women and Men in Conversation. Virago. London.

Wareing, S. (2004). Language and Gender. In L.Thomas et al. Language Society and Power. London and New York: Routledge, 75-92.

Wray, A. \& Bloomer, A. (2006). Projects in Linguistics. London: Hodder Arnold.

Yule, G. (1996). Pragmatics. Oxford: Oxford University Press.

Yule, G. (2006). The Study of Language. Cambridge: Cambridge University Press.

Zimmerman, D. H. \& West, C. (1975). Sex roles, interruptions, and silences in conversation. In B.Thorne \& N. Henley. eds. Language and Sex: Difference and Dominance. Rowley, Mass. Newbury House. Massachusetts, 118.

\title{
SUY NGẪM VỀ CHIẾN LƯỢC LỊCH SỰ TRỰC TIẾP VÃ GIÁN TIẾP THỂ HIỆN QUA VỞ' KỊCH PYGMALION, MỘT TÁC PHẨM TRÀO PHÚNG VỀ PHÉP LICCH SỰ CỦA NHÀ VĂN G. B. SHAW
}

\author{
Đỗ Thu Hương, Nguyễn Việt Kỳ \\ Trường Đại học Ngoại ngũ - Đại học Quốc gia Hà Nội \\ Phạm Văn Đồng, Cầu Giấy, Hà Nội, Việt Nam
}

Tóm tắt: Bài báo nghiên cứu các chiến lược lịch sự trực tiếp (CLLSTT) và gián tiếp (GT) của nam và nữ thể hiện qua phát ngôn của các nhân vật trong vở kịch của nhà văn George Bernard Shaw. Theo lý thuyết về phép lịch sự của Brown và Levinson (1978), việc hiện thực hóa các CLLSTT và GT có liên quan tới hai loại chiến lược hành vi đe dọa thể diện (FTAs): CLLSTT và GT. Trong bài báo này, CLLSGT, trọng tâm của nghiên cứu, sẽ được đánh giá theo các tiểu CLLSGT khác nhau xét về các cách ngôn giao tiếp của Grice (Chân, Túc, Trực, Minh). Các tiểu CLLS này gồm việc sử dụng phép ẩn dụ, trào phúng, câu hỏi tu từ, giản ngôn và lộng ngôn. Tác giả bài báo cũng tiến hành điều tra thống kê tần suất sử dụng CLLSTT và GT của các nhân vật thuộc các tầng lớp xã hội khác nhau trong tác phẩm. Với phương pháp nghiên cứu định tính dựa trên khung lý thuyết về lịch sự của Brown và Levinson (1978), tác giả tập trung vào hai thành tố giao tiếp: giới tính và giai cấp xã hội. Qua vở kịch Pygmalion, khoảng cách giữa giai cấp thượng lưu và hạ lưu trong xã hội Anh vào cuối thế kỷ 19 đã được lột tả thông qua sự khác biệt về cách sử dụng ngôn ngữ của các nhân vật như ngữ âm, từ vựng, ngữ pháp và ngữ dụng.

Tù khóa: phép lịch sự, hành vi đe dọa thể diện, chiến lược lịch sự trực tiếp và gián tiếp 


\section{Appendices}

\section{Appendix 1}

The bald-on-record utterances in the speech of Liza as a flower girl

1. [...] cheer up, Captain; and buy a flower off a poor girl.

2. [...] do buy a flower off me, Captain.

3. Take this for tuppence.

4. [...] don't let him charge me.

5. You just show me what you've wrote about me.

6. [...] don't let him lay a charge agen me for a word like that.

7. Let him say what he likes.

8. Let him mind his own business [...]

9. Buy a flower, kind gentleman.

10. Take the whole blooming basket for sixpence.

11. Don't you be so saucy.

12. Don't mind if I do.

13. [...] don't be silly.

14. Take it or leave it.

15. You give me that handkerchief.

16. Don't you believe the old liar.

The bald-on-record utterances in the speech of Liza as a disguised high-class character

1. Take your slippers [...]

2. Stop, please.

3. Don't you hit me.

4. Don't you try to get round me. You'll HAVE to do without me.

5. Don't sneer at me.

6. Buy them yourself.

\section{Appendix 2}

\section{Mrs. Pearce's bald-on-record utterances}

Sit down, girl. Do as you're told.

You mustn't speak to the gentleman like that.
Don't cry, you silly girl. Sit down.

[...] don't say that, $\operatorname{sir}[\ldots]$.

You must be reasonable, Mr. Higgins: really you must. You can't walk over everybody like this.

You mustn't talk like that to her.

Stop, Mr. Higgins. [...]. Go home to your parents, girl; and tell them to take better care of you.

Will you please keep to the point, Mr. Higgins. [...]. You must look ahead a little.

Come with me, Eliza.

Don't answer back, girl. You don't understand the gentleman. Come with me.

Handle it carefully, sir, please.

But you really must not swear before the girl.

[...] I beg you not to let the girl hear you repeat it.

Mr. Higgins, please don't say anything to make the girl conceited about herself.

[...] don't rush about like that, girl.

\section{Appendix 3}

\section{Mr. Higgins's bald-on-record utterances}

1. Oh, shut up, shut up.

2. Live where you like; but stop that noise.

3. Woman: cease this detestable boohooing instantly $[\ldots]$

4. [...] don't sit there crooning like a bilious pigeon.

5. Come and see me tomorrow.

6. Be off with you: I don't want you.

7. Sit down (5).

8. Come back to business.

9. Figure it out.

10. Hold your tongue.

11. Don't mistake the one for the other if you wish to become a lady in a shop.

12. Take her away and clean her, Mrs. Pearce.

13. Take all her clothes off and burn them. Ring up Whiteley or somebody for new ones. Wrap her up in brown paper till they come. 
14. Take her away, Mrs. Pearce.

15. Put her in the dustbin.

16. Mrs. Pearce: you needn't order the new clothes for her. Throw her out.

17. Now don't make any more fuss. Take her downstairs; and--

18. [...] pay her whatever is necessary: put it down in the housekeeping book.

19. Tell me that, Mrs. Pearce.

20. Pledge of good faith, Eliza.

21. Listen, Eliza.

22. Bundle her off to the bath-room.

23. Come in. Don't burn that, Mrs. Pearce.

24. Send the blackguard up.

25. Take her away at once.

26. Take her away.

27. You're going to take her away, double quick.

28. Give her to him.

29. Take your daughter.

30. Stop. You'll come regularly to see your daughter.

31. Oh, she'll be all right: don't you fuss.

32. Pick: lock up, will you?

33. [...] chuck them over the bannisters into the hall.

34. Put out the lights, Eliza; and tell Mrs. Pearce not to make coffee for me in the morning.

35. Get up. Anything wrong?

36. Sit down and be quiet.

37. Hand them over.

38. Don't you dare try this game on me.

39. Get up and come home; and don't be a fool.

40. Then get out of my way; for I won't stop for you.
41. Very well: be off with you to the sort of people you like.

\section{Appendix 4}

\section{Mr. Doolittle's bald-on-record utterances}

1. I want my daughter: that's what I want. See?

2. Now, now, look here, Governor.

3. Don't take a man up like that, Governor.

4. Be human, governor.

5. So help me, Governor.

6. No, Governor. Don't say that.

7. Listen here--

8. Listen here, Governor.

9. Don't say that, Governor. Don't look at it that way.

10. Therefore, I ask you, as two gentlemen, not to play that game on me.

11. Governor, so help me

12. You give me what I ask you, Governor.

13. Tell her so, Governor: tell her so.

14. Take my advice, Governor: marry Eliza while she's young and don't know no better.

15. Don't put it on me, Governor.

16. Don't you give me none of your lip; and don't let me hear you giving this gentleman any of it neither, or you'll hear from me about it. See?

17. See here! Do you see this?

18. Look at it. Look at this hat. Look at this coat.

19. Tell me this.

20. Don't you be anxious.

21. [...] have some consideration for my feelings as a middle class man.

22. Don't look at me like that, Eliza. 